\title{
KETIDAKJUJURAN AKADEMIK DALAM PENDIDIKAN TINGGI
}

\author{
Agus Ardinansyah $^{1}$, Dhihram Tenrisau ${ }^{1}$, Fuad Aslim ${ }^{1}$, Ismail Suardi Wekke ${ }^{2}$ \\ ${ }^{1}$ Universitas Hasanuddin, Sulawesi Selatan \\ ${ }^{2}$ Sekolah Tinggi Agama Islam Negeri (STAIN) Sorong, Papua Barat \\ Email: $\underline{\text { dhihram.tenrisau@ gmail.com, iswekke@ gmail.com }}$
}

\begin{abstract}
Academic dishonesty which the most common are: cheating or plagiarism. Several studies have shown that behavior of cheating and plagiarism as a major serious problem in academic institution worldwide especially in dentistry. Enforcement of academic ethic and integrity in dentistry should involve institution and supported by the entire academic community of students, faculty, stakeholders and staff. Furthermore, dentistry education should create ethics curricula, which uphold academic integrity and ethical codes, starting with giving attitude of respect and humanism through the method that is known as pedagogy.
\end{abstract}

\begin{abstract}
ABSTRAK
Pelanggaran terhadap etika akademik berbentuk academic dishonesty (ketidakjujuran akademik) yang paling umum adalah menyontek atau plagiarisme. Beberapa penelitian membuktikan bahwa di institusi kedokteran gigi sering terjadi ketidakjujuran akademik berbentuk menyontek dan plagiat. Perilaku menyontek dan plagiat menjadi permasalahan serius di institusi kedokteran gigi seluruh dunia. Penegakan integritas akademik dalam bentuk kejujuran akademik di institusi kedokteran gigi harus melibatkan dan mendapat dukungan oleh seluruh civitas academica mahasiswa, dosen, stakeholder maupun pegawai. Pendidikan dokter gigi kiranya menciptakan ethics curricula, yang menjunjung tinggi integritas akademik dan kode etik akademik, diawali dengan memberikan sikap penghormatan dan humanisme lewat metode yang dikenal dengan pedagogi.
\end{abstract}

\section{Latar Belakang}

Undang-undang No. 20 tahun 2003 tentang sistem pendidikan nasional menyatakan bahwa pendidikan adalah usaha sadar dan terencana untuk mewujudkan suasana belajar dan proses pembelajaran agar peserta didik secara aktif mengembangkan potensi dirinya untuk memiliki kekuatan spiritual keagamaan, pengendalian diri, kepribadian, kecerdasan, akhlak mulia serta ketrampilan yang diperlukan dirinya, masyarakat, bangsa dan negara. ${ }^{1}$ 
Sebagai salah satu institusi pendidikan di Indonesia, program pendidikan kedokteran gigi menerapkan kurikulum berbasis kompetensi yang mengacu pada Standar Kompetensi Dokter Gigi Indonesia. Penerapan kurikulum berbasis kompetensi mencakup tiga ranah yang merupakan elemen-elemen dasar pembentuk kompetensi professional yaitu pengetahuan, keterampilan dan sikap atau etika. ${ }^{2,3,4}$

Etika berasal dari kata ethos dalam bahasa Yunani Kuno, yang berarti kebiasaan, adat, akhlak, watak, perasaan, sikap, atau cara berfikir. ${ }^{5}$ Sementara itu, menurut Franz Magnis Suseno, etika bukan suatu sumber tambahan bagi ajaran moral, melainkan merupakan filsafat atau pemikiran kritis dan mendasar tentang ajaran-ajaran dan pandangan-pandangan moral. Etika adalah sebuah ilmu, bukan sebuah ajaran. ${ }^{6}$

Etika dalam proses pendidikan disebut etika akademik. Menurut Redioka, dapat diartikan sebagai ketentuan yang menyatakan perilaku baik atau buruk dari para anggota civitas akademica perguruan tinggi, ketika mereka berinteraksi dalam kegiatan yang berkaitan dengan ranah dalam proses pembelajaran. ${ }^{7}$

Pelanggaran terhadap etika akademik berbentuk academic dishonesty (ketidakjujuran akademik) yang berbentuk menyontek atau plagiarisme. Istilah terhadap ketidakjujuran akademik ini bisa dibilang masih membingungkan dan cakupan yang luas. Pavela mendefinisikan komponen yang menjelaskan ketidakjujuran akademik yang paling jelas adalah menyontek atau plagiarisme. ${ }^{8}$

Nyatanya etika akademik dalam pendidikan tinggi masih menjadi problematika di kampus dan universitas di berbagai belahan dunia, sama halnya dengan institusi kedokteran gigi. Pelanggaran terhadap etika akademik tersebut seringkali dalam bentuk ketidakjujuran akademik. 
Bahkan sebuah survey yang dilakukan di Amerika Serikat dan Kanada menggambarkan bahwa menyontek dan plagiarisme sebagai isu utama yang mengancam integritas akademik pada institusi pendidikan tinggi. ${ }^{9,10}$ Di Indonesia, pendidikan kedokteran gigi masih sangat jarang membahas lebih dalam tentang etika akademik maupun integritas akademik dalam penerapan kejujuran akademik.

\section{Mahasiswa dan Etika Akademik}

Perguruan tinggi merupakan masyarakat akademik yang mekanisme kerjanya akan terikat pada etika-moral untuk melaksanakan misi dan tugas Tridharma perguruan tinggi yang disandangnya. Etika dalam proses pendidikan disebut etika akademik. Redioka mendefinisikan, sebagai ketentuan yang menyatakan perilaku baik atau buruk dari para anggota perguruan tinggi, ketika mereka berinteraksi dalam kegiatan yang berkaitan dengan ranah dalam proses pembelajaran.. 7,11

\section{Kejujuran Akademik, Menyontek, dan Plagiarisme}

Isitilah ketidakjujuran akademik, academic misconduct (perilaku buruk berakademik),dan menyontek nyatanya berubah-ubah pada literatur. Pusat Integritas Akademik menjelaskan bahwa ketidakjujuran akademik sebagai perilaku tidak jujur yang berhubungan dengan pencapaian akademik termasuk menyontek, plagiarisme, berbohong, penipuan dan mengambil keuntungan secara tidak etis. ${ }^{11}$ William L. Kibler mendefinisikan ketidakjujuran akademik yang paling umum adalah menyontek dan plagiarisme, dengan melibatkan mahasiswa baik yang memberi ataupun menerima di dalam proses akademik atau menerima upah dari pekerjaan yang tidak dilakukan. $^{13}$

Plagiarisme oleh Mason, didefinisikan sebagai menggunakan ide, kata, atau pemikiran seseorang, tanpa melampirkan dengan jelas sumbernya. Penulis ataupun pengarang seharusnya 
diberi penghargaan dengan minimal dicantumkan terhadap produk pengetahuan yang mereka buat. Hal itu menjadi masalah akademik yang serius dan menjadi permasalahan etis yang mendapatkan perhatian besar secara global dalam kepenulisan biomedis. ${ }^{14,15}$

Cheating atau menyontek lebih mencerminkan perilaku dibanding karakteristik dari tindakan mahasiswa. Menyontek ini tidak hanya terbatas pada saat ujian. Menyontek dapat terjadi pada kegiatan laboratorium dan di klinik dengan memalsukan rekam medis pasien. Hal tersebut dapat terjadi dengan memalsukan tanda tangan atau stempel fakultas pada resep obat atau disertai pengambilan biaya pribadi dari perawatan pasien. ${ }^{12}$

Penelitian di Taiwan menunjukkan bahwa dari 2.068 mahasiswa, 61,72\% melakukan ketidak jujuran akademik. Pelanggaran itu juga terjadi di banyak institusi pendidikan. ${ }^{16}$ Pada penelitian tahun 1972, 93\% dari mahasiswa menyatakan bahwa menyontek telah menjadi suatu hal normal dalam hidup. Temuan McCabe, Trevino \& Butterfield bahwa alasan mahasiswa berlaku curang adalah untuk memperoleh kesuksesan di pendidikan untuk mendapakan kerja ataupun hanya sekedar menamatkan pendidikan. ${ }^{12,17}$ Sayangnya, para mahasiswa menganggapnya sebagai sesuatu yang wajar. Semisal pada penelitian Taradi dkk, pada 1074 mahasiswa kedokteran di Kroasia, di mana 97\% mengakui melakukan menyontek dan plagiarisme.

Di beberapa negara, utamanya di negara berkembang yang di mana pelatihan riset biasanya diletakkan pada level pendidikan strata satu, memiliki lingkungan baik untuk melakukan riset, pelatihan yang adekuat, dan adanya penggunaan dari software pendeteksi plagiarisme. Ba`zdari'c dkk, melaporkan prevalensi jurnal plagiat yang terdapat pada Croatian Medical Journal selama 2009-2010 meningkat. ${ }^{18}$ Bahkan temuan dari Schemo, menunjukkan di 
sebuah kelas di Unviersitas Ohio, banyak dari mahasiswa kelas tersebut terbukti melakukan menyontek dan plagiarisme pada beberapa karya ilmiah rekan mereka. ${ }^{13}$

\section{Kasus Pada Institusi Kedokteran Gigi}

Beberapa penelitian membuktikan bahwa mahasiswa di fakultas teknik, matematika, kedokteran, ekonomi lebih sering menyontek daripada mahasiswa di fakultas ilmu-ilmu sosial dan humaniora. ${ }^{16,19}$ Sama halnya yang terjadi di institusi kedokteran gigi, perilaku menyontek dan plagiat menjadi permasalahan serius di institusi kedokteran gigi seluruh dunia., ${ }^{9,20,15}$

Al-Dwairi yang melakukan studi di Fakultas Kedokteran Gigi di University of Science and Technology di Yordania, menemukan perilaku menyontek dilakukan 85\% dari 200 mahasiswa strata satu. ${ }^{20}$ Sama halnya yang dilakukan pada 1.261 mahasiswa strata satu juga 131 dosen dari fakultas kedokteran gigi di Tamil Nadu, India, di mana sebanyak 95\% pernah menyontek. Jumlah yang hampir sama ditemukan di Amerika Serikat. ${ }^{9}$

Para dosen dan staff juga faktanya melakukan perilaku plagiarisme. ${ }^{21,22}$ Bahkan hampir seluruh staff fakultas mengetahui hal tersebut. ${ }^{23}$ Survey menyatakan 37 dari 46 institusi kedokteran gigi di Amerika Serikat, ditemukan adanya kecurangan, sepertiganya berdasarkan teknologi. Selain itu ditemukan 30 metode kecurangan dari 14.000 mahasiswa kedokteran gigi tersebut. ${ }^{24,25}$ Pelanggaran akademik yang paling banyak dilakukan oleh mereka adalah, melakukan plagiarisme bersama rekan mereka. Mereka bekerja sama untuk menyontek. Insiden tersebut meningkat tiga kali lipat dari 1998 hingga 2013. Hanya 27\% institusi di Amerika Serikat yang dilaporkan jarang terjadi kasus ketidakjujuran akademik. 9,22,23

- Penelitian Al-Dwairi dan Asokan terhadap perilaku ketidakjujuran akademik, menunjukkan bahwa persepsi yang paling dianggap permasalahan paling serius pada mahasiswa 
kedokteran gigi, plagiarisme dan perilaku menyontek masuk dalam empat yang dikategorikan oleh para mahasiswa sebagai permasalahan serius, selain itu memalsukan nama fakultas dalam status pasien untuk keuntungan pribadi serta dengan sengaja salah menuliskan perawatan pada rekam medis pasien, masuk dalam dua besar. ${ }^{20,21}$

\section{Institusi Pendidikan dan Integritas Akademik}

Integritas akademik adalah kejujuran dalam semua hal yang berhubungan dengan lingkungan akademik. Lingkungan yang jamak tersebut mencakup proses belajar-mengajar, kemampuan, juga nilai serta penemuan dari pengetahuan baru. Dalam pendidikan dokter gigi, lingkungan tersebut mencakup diagnosis, perawatan, serta komunikasi dengan pasien. Kesemua pelayanan dalam komunitas membuat diperlukannya hal tersebut dalam pendidikan. paling umum dalam penerapan integritas akademik adalah pelarangan terhadap perilaku menyonek, tindakan plagiat dalam tugas tulisan, atau memalsukan dokumen untuk institusi. Integritas akademik adalah nilai dasar dari segala kegiatan pendidikan. Ketidakjujuran akademik adalah salah satu bentuk pelanggaran terhadap integritas akademik. ${ }^{26}$

Banyak faktor yang menyebabkan lahirnya perilaku ketidakjujuran akademik khususnya menyontek dan plagiarisme. Faktor situasional seperti: tekanan mendapat nilai tinggi, kontrol dan pengawasan selama ujian, kurikulum, pengaruh teman sebaya, ketidaksiapan mengikuti ujian, iklim akademis di fakultas. Faktor personal seperti: kurang percaya diri, self esteem dan need approval, ketakutan terhadap kegagalan, kompetisi dalam peringkat akademik, selfefficancy. Faktor demografi seperti: jenis kelamin, usia, IPK, penilaian moralitas, riwayat pendidikan sebelumnya, serta fakultas atau jurusan., 9,17,19 
Penelitian yang dilakukan Bowers tahun 1964 menyatakan adanya kode etik dalam institusi akademik memiliki hubungan dengan tingkat menyontek atau plagiarisme yang lebih rendah. Pada penelitian yang lain McCabe dan Trevino menemukan hal yang berbeda pada salah satu institusi dimana tingkat menyontek yang sangat rendah tetapi institusi tersebut tidak memiliki kode etik formal. Setelah diteliti lebih jauh institusi tersebut mengembangkan suatu budaya yang menanamkan banyak elemen yang terdapat dalam kode etik formal. Pihak fakultas termasuk administrator/pengajar menyampaikan secara jelas keyakinan mereka tentang seriusnya dampak perilaku mencontek, ekspektasi mereka yang tinggi terhadap integritas, dan mendorong mahasiswa untuk tahu dan mau melakukan perilaku yang seharusnya. Penemuan ini memberikan pandangan yang penting, bahwa bukan hanya adanya kode etik yang efektif mencegah perilaku menyontek, tetapi kode etik yang paling efektif harus diimplementasikan dan ditanamkan dengan baik dalam budaya mahasiswa. ${ }^{17}$

Graham B, dkk menyarankan perlunya ethics curicula, dalam hal ini bisa disebut mata kuliah etik yang menanamkan kesadaran untuk mencegah adanya ketidakjujruan akademik. ${ }^{22}$ Namun nyatanya terdapat kekurangan yang dapat dilihat dari ethics curricula yaitu: 1) pemahaman dari etika tidak dapat hadir dari pendidikan lebih, 2) mata kuliah etika tidak menarik, dan 3) mahasiswa tidak dapat berpartisipasi secara aktif di dalam pembelajaran dari etik. Bertolami kemudian menyarankan suatu mata kuliah awal, dengan model pembelajaran partisipatif di dalam lingkungan akademik. ${ }^{9}$

Untuk memulai hal tersebut, mahasiswa harus diberlakukan dengan hormat sebagai suatu teman sejawat yang profesional oleh staf fakultas. Mahasiswa akan lebih merespon positif untuk segala kewajiban etis, saat mereka diperlakukan selayaknya profesional. ASDA (American 
Student Dental Association), juga menambahkan perlunya lingkungan untuk mahasiswa dan kampus untuk menunjang terwujudnya kesadaran kritis akan etika akademik.

Pendidikan dokter gigi harus memberikan sikap penghormatan dan humanisme, hal tersebut juga relevan jika dilakukan praktek, sebagai metode yang dikenal dengan pedagogi, untuk menggali kesadaran kritis sebagai puncak kesadaran akan permasalahan mereka. Diharapkan adanya portofolio refleksi, yang membantu mahasiswa dapat menilai sendiri dan mengevaluasi segala pengetahuan, kemampuan atau permasalahan yang dihadapi. ${ }^{22,25}$

Penelitian lainnya menyarankan mengurangi tindakan penghukuman dan menyarankan konseling juga mengingatkan mahasiswa bersangkutan. ${ }^{21}$ Spallek menambahkan bahwa perlunya pengawasan terhadap teknologi khususnya pemakaian ponsel,internet dan gadget lainnya selama kegiatan akademik untuk mencegah plagiarisme dan perilaku menyontek. ${ }^{26}$

Penelitian ini diharapkan dapat menjadi pemantik penelitian etika penyelenggaraan pendidikan di institusi kedokteran gigi, khususnya di Indonesia yang masih minim. Perlu dilakukan penelitian lebih lanjut dan lebih komprehensif. Perlu pula dilakukan persamaan persepsi akan istilah seperti menyontek dan plagiarisme.

\section{Kesimpulan}

Ketidakjujuran akademik sebagai pelanggaran etika akademik dalam bentuk menyontek dan plagiarisme pada pendidikan tinggi, masih menjadi problematika institusi pendidikan kedokteran gigi di seluruh dunia. Penegakan integritas akademik dalam bentuk kejujuran akademik di institusi kedokteran gigi harus melibatkan dan mendapat dukungan oleh seluruh civitas academica mahasiswa, dosen, stakeholder maupun pegawai. Penegakan kejujuran akademik dapat diawali dengan cara menciptakan lingkungan yang humanis dan memicu 
kesadaran kritis akan etika akademik. Berbagai upaya tersebut diharapkan bisa meminimalisir hal yang bisa mendorong mahasiswa untuk melakukan pelanggaran akademik.

\section{Daftar Pustaka}

1. Undang-undang No. 20 tahun 2003 tentang Sistem Pendidikan Nasional.

2. Konsil Kedokteran Indonesia. Standar Kompetensi Dokter Gigi Indonesia. Jakarta. 2008

3. Departemen Pendidikan Nasional. Suasana Akademik.Jakarta. 2005

4. Pengurus Besar Persatuan Dokter Gigi Indonesia. Kode Etik Kedokteran Gigi. 2008

5. Badan Pengembangan dan Pembinaan Bahasa, Kemdikbud. Kamus Besar Bahasa Indonesia. Versi Online Ed 3

6. Suseno FM. Etika Dasar: Masalah-masalah Pokok Filsafat Moral. Yogyakarta: Kanisius. 1987

7. Redioka NA. Etika Akademik Sebagai Landasan Penjaminan Mutu Pendidikan Tinggi. Diakses di http://redioka.wordpress.com/2012/11/05/etika-akademik-sebagai-landasanpenjaminan-mutu-pendidikan-tinggi/

8. Bourassa MJ. Academic Dishonesty: Behaviors and Attitudes of Students at ChurchRelated Colleges and Universities. Theses and Disertation. University of Toledo Repository.2011

9. Andrews KG. Faculty and Student Perceptions of Academic Integrity at U.S. and Canadian Dental Schools. J Dent Educ 2007;71:1027-39

10. Finn, K.V. \& Frone, M.R. 2004. Academic Performance and Cheating: Moderating Role of School Identification and Self-Efficacy. JDentEduc. 97,115-162. 
11. Dardiri. Etika Akademik. Makalah dipresentasikan di Fakultas Pertanian UPN Yogyakarta. 19 Nov 2003

12. Wideman MA. Academic Dishonesty in Postsecondary Education: A Literature Review. Transformative Dialogues: Teaching \& Learning Journal 2008;Vol 2

13. Ercegovac Z, Richardson Jr. JV. Academic Dishonesty, Plagiarism Included, in the Digital Age: A Literature Review.

14. Rathore FA, et al. Exploring the attitudes of medical faculty members and students in Pakistan towards plagiarism: a cross sectional survey. PeerJ, DOI 10.7717/peerj.1031

15. Rösing CK, Cury AADB. Self-plagiarism in scientific journals: an emerging discussion. Braz Oral Res., (São Paulo) 2013 Nov-Dec;27(6):451-2

16. Lin, C.H.S. \& We, L.M. 2007. Academic Dishonesty in Higher Education- Nationwide Study in Taiwan. Higher Educational Journal. 54, 85-97.

17. McCabe DL. et al. Cheating in Academic Institutions: A Decade of Research. Ethics and Behaviour. Vol 11, issue 3. 2001

18. Ba`zdari'c K, Bili'c-Zulle L, Brumini G, Petrove`cki M. Prevalence of plagiarism in recent submissions to the Croatian medical journal. Science and Engineering Ethics 2012: 18(2):223-239

19. Mujahidah. Perilaku Menyontek Laki-Lakidan Perempuan: Studimeta Analisis. Fakultas Tarbiyah, Sekolah Tinggi Agama Islam Negeri, Samarinda 75111

20. Al-Dwairi, Al-Wahaedi. Cheating Behaviors of Dental Students. J Med Educ 2004;68(11):1192-95

21. Asokan S, dkk. Attitudes of Students and Teachers on Cheating Behaviors: Descriptive Cross- Sectional Study at Six Dental Colleges in India. 
22. Graham BS, dkk. Dental Student Academic Integrity in U.S. Dental Schools: Current Status and Recommendations for Enhancement. J Med Educ 2013;77(10):1379-83

23. Beemsterboer PL, Odom JG, Pate TD, Haden NK. Issues of academic integrity in U.S. dental schools. J Dent Educ 2000;64(12):833-8

24. Hutchins B, Cobb S. When will we be ready for academic integrity? J Dent Educ 2008;72(3):359-63

25. Freire P. Pedagogy of the Oppressed. Bloomsbury Academic; 1968

26. Spallek H, Academic Dishonesty-How to Detect It and How to Prevent It. Dipresentasikan di University of Pittsburgh, School off Dental Medicine, ADEA 2014

27. Turner PS, Enhancing Academic Integrity: Formulating Effective Honor Codes. J Dent Educ 2003;67(10):1122-29 